\section{DISCURSO DO PARANINFO}

\section{Edgar Luiz Schneider}

Discurso proferido na solenidade de cola cão de grau dos bacharelandos, realizada no Saläo Nobre da Fac. de Dir. em 22 de março de 1949.

"Mais alta dentre as festas acadêmicas, a conferição do grau que recebeis, ao cabo de vossos estudos, não ocasiona apenas transportes de júbilo, senão que acoroçoa e justifica, sob as franquias da experiência e da ponderação, um enaltecimento à carreira que encetais, em plena vigília de projetos e de esperanças.

Afora as virtudes, que trazeis de berço, eis que esplendem, nas primazias da exaltação generosa, os auspícios que vos sorriram, através do curso universitário, ao fulgor da tradição e pela seqüência de ensinamentos duradouros.

\section{A VELHA FACULDADE}

São de encantamento e de orgulho, por certo, as impressões que dominam quantos remontam ao alvorecer da nossa Faculdade, acompanhando e surpreendendo, em meio-século de total devotamento ao ensino jurídico, a sua ascensão e os seus triunfos.

Modesta e afanosa, nas suas origens, logrou subsistir e frutificar, porque acudia a um imperativo da época e tinha por si a fulguração e a intrepidez de nobres paladinos.

Servida dessa vanguarda, que dava lustre e vigor aos anseios comuns, a campanha prosseguiu e se enriqueceu, graças ao estuário aberto ao entusiasmo e à cooperação de todos os espíritos, entre os quais sobressaía a paixão da justiça e da liberdade.

Animadores e depositários, que se faziam da consciência militante, é sabido que os idealizadores dêste instituto de ensino, sensíveis à sua voz interior, nunca recuaram de sacrifícios, contanto que abreviassem e fortalecessem a consecução da grandiosa iniciativa.

Fora do patrocínio oficial, visto que repousava inteiramente sôbre os recursos obtidos e afiançados pelos seus fundadores, a Faculdade de Direito de Pôrto Alegre, desvelada nos misteres escolares, muito cedo volvia à edificação da própria sede, que se destaca, ainda hoje, entre os mais belos exemplares do estilo renascença da metrópole rio-grandense.

Quase não se pode, nessa diligência portentosa, distinguir entre a convicção, que perseverava e o esfôrço, que construía, pois em ambos havia uma predestinação superior, cujo sentido estêve presente às várias gerações, ao longo do ciclo acadêmico, transmitindo a tôdas um sadio idealismo.

Partícipes que sois dêsse legado, não estranheis que o exalce; pondo em relêvo, numa evocação fugaz, os seus artífices, que o foram pela consagração ao magistério e persistem entre as recordações mais caras pela personificação da dignidade e desinterêsse.

Mestres que souberam fazer da cátedra, engrandecendo-a e aureolando-a, um apostolado constante e fecundo, é inquestionável que ao influxo de suas lições, repassadas da sabedoria sem meandros, muitas foram as controvérsias, que se dirimiram e não poucos os princípios que se renovaram.

Entretanto, nessa faina magistral, que se desatou em lavores peregrinos, não ganharam apenas as idéias, sutilizadas pelo debate e pela reflexão, senão que maior conquista realizou, ao contato do professor e atenta às suas preleções, a própria mocidade estudiosa.

\section{SUGESTIVA COINCIDENCIA}

Renovando a crédito da Faculdade, como o fizeram as anteriores, os benefícios que receberam, a atual turma de bacharéis completa a sua jornada às vésperas do cinqüentenário da fundação da escola, que cursaram.

Nessa ocorrência feliz, são múltiplas e variadas as reflexões que acodem ao espírito, tendo à vista a gloriosa rotação do instituto universitário, que não cessou nunca de aumentar a sua prole, em cujo seio sobressaíram tantos e prestimosos expoentes da advocacia e da magistratura, da administração e do Parlamento.

Tanto mais de realçar a coincidência, quanto é certo que a presente colação de grau, fiel como as demais a seu conteúdo espiritual, assume uma feição mais solene, desde que a prestação do juramento se efetua dentro do rigor pragmático, que as vestes talares conferem.

Acrescida embora a sua majestade, é preciso advertir que a consumação desta cerimônia, imponente e sugestiva, não esgota a própria finalidade, pois não consiste só em celebrar uma tarefa terminada, senão ainda em augurar uma faina, áspera e grave, que apenas principia.

Entretanto, nunca houve talvez uma geração que, à semelhança da vossa, meus jovens afilhados, defrontasse um mundo mais revôlto e menos oscilante, nos seus fundamentos e nas suas tendências.

Resultou isso do fervor sectário que, ao serviço da negação de essenciais prerrogativas humanas, bafe aram e difundiram os regimes de fôm esnonsives pela suerra e sobretudo pela inquietação que, pior ainda, atormenta e desespera os povos civilizados. 


\section{ANSEIOS QUE AVULTAM}

Ora, cultores que sois do direito, não podereis subtrair-vos, mercê da própria vocação, às angústias do século, que desafiam e reclamam, numa crescente dramaticidade, soluções corajosas e duradouras.

Nos dias atuais, os homens não cuidam apenas resguardar a inviolabilidade pessoal, senão que reivindicam, como primordiais, os direitos à liberdade e ao bem-estar.

E' pacífica a convicção que a universalização dêsses princípios, à guisa de mandamentos de observância invariável, seria o esteio vivo da segurança e a maior garantia da paz mundial.

Mas, embora convirjam, nessa direção, tôdas as aspirações, as quais também se incorporam nos programas partidários e aparecem nas plataformas oficiais, é fora de dúvida que ainda longe estão de objetivar-se, em proporção sequer razoável, nas práticas habituais de govêrno.

Não custa a explicar, todavia, as razões do contraste que frisa as incongruências da atualidade política, em cujo cenário se assinala um divórcio entre as ideologias militantes e as providências em voga, menos pela impossibilidade de realização que pelo caráter contraditório e inconseqüente das medidas adotadas.

E' o que salienta Georges Rippert ao exprimir que "tôda revolução social deve ser ao mesmo tempo uma revolução jurídica, sem o que ela não será senão vã desordem política".

Foi o que aconteceu aos sistemas totalitários, pois menos que a instauração da justiça social, objeto da propaganda sectária, eis que a lógica do govêrno consistiu em fazer da discriminação e do arbítrio, dentro do misticismo reinante, os meios comuns do Estado.

\section{ECONOMIA AUTORITÁRIA}

Inteiramente fora do âmbito democrático, que não comporta a negação do direito, a intervenção oficial, nas diferentes atividades individuais, contraiu uma feição tìpicamente autoritária.

Visando a conjurar, ou a resolver as crises, sob o pretexto de acautelar o bem comum, que merece defendido, ao invés de as dirimir, muito ao contrário só as exasperou e desenvolveu, mercê da burocracia esterilizante e avassaladora.

Responsáveis pelo surpreendente desenlace, é evidente que haviam de mostrar-se, pertinazes e conjugados, o dirigismo e a planificação, arvorados em molas reais da engrenagem oficial.

Sem excluir as limitações impostas pelo interêsse público, recusadas ou talvez mal-entendidas pelo liberalismo, não há duvidar que a nova mística, propícia à índole cesárea de seus artífices, toma a si o comando geral da vida social e econômica, segundo um plano preconcebido e cuja execução é confiada aos agentes do Estado, fora de todos os quadros do equilíbrio natural.

Centro de gravitação da economia dirigida, o planejamento encerra a fonte de milagres, mediante os quais cuidam seus pregoeiros. resolver as múltiplas incógnitas econômicas e, sem embargo dessa crença, as decepções se sucedem e acumulam, varrendo os demais planos do campo considerado, onde só domina a planificação governamental, que constitui porisso mesmo e a juízo do professor Hayek, a negação de tôda a liberdade.

Ganglionando-se em diferentes setores, com ou sem a ação planejadora, a política dirigida abraça e submete ao próprio império a economia inteira da produção e da troca, tendo de permeio a moeda e o crédito, sem nunca atender senão agravar as instâncias do consumidor, através de promessas malogradas.

Estão muito vivas, entre os observadores mundiais, as conseqüências do dirigismo nos países que o adotaram como remédio para todos os males, que paradoxalmente subsistiram, acrescidos pelo espírito de opressão, de intolerância e de guerra.

Mas, os malefícios do sistema, entre os quais assoma, em realce estarrecedor, o nacionalismo aduaneiro, repercutem perturbadoramente nas esferas internacionais.

$E^{\prime}$ interessante observar que, em plena voga da economia dirigida, o que se verifica é a fome justamente quando abundam os alimentos e, ao invés de enviá-los aonde faltam, é a sua destruição que as elites dirigentes aconselham e propugnam.

A medida preconizada é a do maltusianismo econômico, que consiste em indenizar ao produtor as sobras do café lançado ao mar, matar os carneiros da Austrália por valerem menos que a própria forragem, queimar o trigo em superprodução.

\section{A REAÇÃO DA EXPERIENCIA}

Foi a evidência de tantos fatos, que perduram à face da terra, não obstante as experiências recentes, a razão maior por que alguns congressos internacionais, questionados acêrca da inquietação generalizada, enveredaram francamente pelo combate ao regime dominante, optando pela liberdade do comércio e da indústria.

Primeira dentre as conferências interamericanas, que se manifestou, a êsse respeito, a do México acentuou a precisão de "preservar e robustecer a liberdade de ação no terreno econômico", não destoando do asserto as reuniões subseqüentes, inclusive a de Chicago, última e mais importante de tôdas.

Evidentemente, ninguém deixará de admitir, nesse campo de atividades, a interferência do Estado, contanto que obedeça a um 
umperativo social, como seja principalmente de obstar ou reprimir os desmandos da especulação ilícita, mediante a correção de abusos e a tutela do bem coletivo.

Contudo, só onde a ação particular estiver ausente, fôr molesta ou sem eficiência, caberá a intervenção oficial, devendo sempre aspirar, menos ao predomínio, ou à duração indefinida, que ao propósito de coordenar, assistir e fortalecer as ocupações nas mãos daqueles que melhor possam servir ao interêsse geral.

Se salvar a liberdade contra tôdas as fôrças que a ameaçam é, a juízo de Francisco Nitti, "o maior problema da nossa civilização", não deve ela sofrer senão as limitações ditadas pelo bem comum, entendido como a linha de sobrevivência, nas lutas da competição social e econômica.

Mas, em qualquer caso, a ingerência do executivo deverá ocorrer dentro da adequada ordenação legal, sem que aos responsáveis seja possível extra-limitar-se nas suas funções, antes perturbando que atendendo os interêsses vitais da coletividade.

E' conhecida a variedade e a extrema abundância de órgãos burocráticos de direção e de contrôle, uns justificáveis e outros escusados, que emergiram do estado de guerra.

Terminada a conflagração mundial, que os ditara, a extinção de todos, segundo as melhores razões, seria uma decorrência insuscetível de controvérsia.

A despeito disso, a maioria dêsses organismos continua de pé, sem nenhuma utilidade aparente, tanto que não desapareceram os problemas, cuja solução poderia ainda esclarecer, sem justificar a sua existência.

\section{DENTRO DA LEGALIDADE}

Manifesta e real é, portanto, a necessidade de reconduzir os quadros da economia ao regime da legalidade, e, dentro dela, encarar e resolver as questões ocorrentes, nas quais se consubstanciem os imperiosos reclamos da comunhão social.

Instaurada uma ordem jurídica, capaz de assegurar um esfôrço harmônico e combinado do capital e do trabalho, maior será o rendimento de ambos, que as excessivas e inconvenientes intervenções do Estado sobremodo entorpeceram e reduziram.

Dessarte, não serão apenas prevenidos os conflitos, senão ainda elevados os níveis de vida, dentro do sistema de cooperação e iniciativa privada, que se impõe, nos dias em curso, como uma verdadeira luta a favor da liberdade e do progresso.

E' de convir, realmente, que a livre emprêsa oferece a todos os homens, como unidades de trabalho e de consumo, iguais oportunidades e retribuição proporcional.
Suficiente será atentar nos resultados que aos Estados Unidos advieram da "free enterprise", em cuja prática, assentada sôbre a faculdade de investir, de aperfeiçoar e de dispor, sem detrimento do bem-estar geral, avultaram a emulação, a eficiência e a segurança.

\section{LIBERDADE E JUSTIÇA}

Não se esqueça, em nosso país, que ainda se mostra saudoso de suas lições, a palavra oracular de Rui Barbosa, quando asseverava convictamente que, "fora da liberdade, não sonhe ninguém a verdadeira prosperidade, material ou intelectuál".

Evidentemente, "a liberdade organizada pela justiça", que Clóvis Beviláqua, em memorável saudação a Pedro Lessa, considerava "a expansão normal de cada indivíduo ou agrupamento de indivíduos, tão ampla e tão intensa quanto fôr possível, sem perturbação da atividade lícita dos outros, e sem oposição aos interêsses vitais da sociedade".

Não se poderiam talvez reunir, em síntese mais perfeita, quanto - fêz o pranteado autor do Código Civil, os aspectos centrais da solução que reclama o problema social, pôsto em têrmos jurídicos.

Mas, a simplicidade aparente das fórmulas, não exclui porque implica, muitas vêzes, a sua complexidade real, que sempre a defrontou entre nós, a formação econômica do país.

E' sabido que a lenta evolução da colônia teve, como seus fatôres decisivos, a escravidão e o direcionismo oficial, fértil em monopólios e em proibições, que se implantaram e mantiveram ao arrepio das condições naturais tôdas favoráveis ao surto ascensional de suas fôrças vivas.

\section{SENTIDO DA INDEPENDENCIA}

A geração da independência não se deixou apenas fascinar pela autonomia política, pois seus batalhadores se moviam, sobretudo, pelo desejo de estabelecer a liberdade, como ambiente imprescindível à exploração útil das riquezas, que estagnavam sob os influxos do mercantilismo da metrópole.

Nas primeiras medidas adotadas pela Nação que surgia, como a abertura dos portos e a supressão do regime colonial, ficara evidenciada a orientação superior, que seus fundadores sufragaram, tendo em mira acelerar o ritmo às energias criadoras.

Quanto se realizou de fecundo e de útil, ao longo do Império, nos arraiais da economia nacional, retratou-se nos índices de progresso e bem-estar, que maiores ainda o seriam, não fôra a permanência do braço escravo, retardatário e minguado nos seus efeitos

Nascido embora sem a mácula da escravidão, abolida que fôra ano e meio antes de proclamado, o regime republicano tinha, a seu favor, um clima propício às mais auspiciosas iniciativas, muitas den- 
tre as quais lograram a fortuna de enraizar-se e florescer, dando ao país um aspecto geral de confôrto e prosperidade.

Contudo, não tardou que a intervenção do Estado, condenada vivamente pelo Congresso de Taubaté, viesse a exercer-se sôbre a rubiácea paulista, empolgada pelas miragens da valorização.

Tanto bastou para que outras plantações fôssem abandonadas e substituídas pelo café, que assentou a sua supremacia, em razão do protecionismo oficial, cuja influência perturbou, profunda e duradouramente, a estrutura nacional da produção e da troca.

\section{OS MALEFÍCIOS DA INTERVENÇÃO}

Disso convence a observaçã́o peremptória de J. E. Normano, professor da Universidade de Harvard, ao afirmar que o "caráter monocultor da economia brasileira tornou o país escravo dos preços mundiais", ao mesmo passo que a defesa governamental de seus. produtos "prejudicou a seleção natural e o progresso técnico".

Entretanto, a segunda conflagração superou a primeira nos seus reflexos sôbre as nossas atividades econômicas, nas quais o govêrno interferiu, larga e diuturnamente, por via de providências que espelhavam os objetivos mais diversos e contraíam as formas mais diferentes.

Ainda não houve, ao que conste, um ramo da administração pública, tão fértil em promessas e tão perdulário em decepções, ao ponto de convergir sôbre si, em permanente contenção de espírito, as: amargas críticas da Nação inteira.

Entre os múltiplos organismos, que apareceram, bastaria nomear os encarregados de vigiar e de regular a produção e o comércio, racionando consumos, fixando preços, concedendo licenças, baixando proibições, promovendo inquéritos, distribuindo estoques, punindo infratores, sem falar nos institutos que avocam a si, mercê de autoridade sem contraste, a preordenação econômica de certos artigos, entre os quaịs avultam o açúcar, o álcool, o sal, o pinho, o arroz, o vinho, o mate.

Quase não há produto que, entre nós, não esteja adstrito às comissões especiais, ou enquadrado nos fins de alguma entidade, portadora de autonomia conferida pelo poder público.

Um exame sumário persuade do excesso de órgãos entre cujas mãos se dirigem e manipulam os interêsses da produção e do consumo, como se o país estivesse em plena economia de guerra, ou não pudesse subsistir sem a tutela do Estado, exercida através de delegados seus, investidos de puro arbítrio.

\section{BARREIRA AO ARBÍTRIO}

Ora, a ingerência oficial, nesses domínios, não mais se concebe e menos ainda se admite depois da queda do regime discricionário. -e ante os têrmos da constituição de 18 de setembro de 1946 que assenta a ordem econômica sôbre os princípios de justiça social, mediante prévia conciliação da liberdade de iniciativa e da valorização "do trabalho humano, como base da nossa democracia renascente.

Dessarte não será lícito ao Estado intervir, ou monopolizar indústria ou atividade, a menos que o interêsse público o exija e sejam respeitados os direitos fundamentais do cidadão, antecedendo sempre lei especial.

Afora o mérito duvidoso de muitas iniciativas oficiais, que não surtiram os efeitos anunciados, mister é convir que, entre elas, não são poucas que infringem a constituição vigente, assim pelos textos nos quais se baseiam, como pelas ações nas quais persistem, uns e outras só explicáveis em sistema ditatorial.

Portanto, a revisão da legislação extravagante e a subordinação da administração e do govêrno, nas suas funções normais, ao primado do direito, é a cruzada mais alta que, nesta hora incerta, se abre ao concurso fecundo de seus nobres cultores.

Estabelecido que foi, em nosso país, um regime democrático, não há hesitar em fazer dêle, nas circunstâncias mais diversas, objeto de respeito e intransigente observância, a bem da ordem e prosperidade comuns.

\section{A DEMOCRACIA REAL}

Mas, no Brasil é evidente que, fiel à sua vocação, só deve e pode interessar, consoante as palavras do gênio da Haia, "uma democracia, educada no direito, adstrita à legalidade e subordinada à justiça".

Foi a sua instituição e, sem dúvida, a contemplação da própria realidade, que levou os jovens bacharéis, sagrados neste ato, à adoção do lema - "jure ordineque civem libertas gerit".

Com efeito, só a liberdade emergente da ordem jurídica é que produz o cidadão, como titular de direitos e credor de bem-estar, convivendo e trabalhando entre seus semelhantes, sem privilégios e sem atritos.

A missão que, dessarte toma a si, em pleno surto renovador do Brasil, a presente geração de soldados do direito, entre os quais recresce e se alonga, nesta solenidade magnífica, o entusiasmo e a generosa confiança de tantos batalhadores, é alguma coisa de grandioso e de venerável.

Deveis ter, pois, presente ao espírito, meus jovens colegas, que a obra do jurista, na frase de laureado professor da Faculdade dé Paris, "é a única que fica quando o tumulto das revoluções se abranda e desvanece".

E' a tarefa, que vos aguarda e o destino superior, que vos almejo". 